\title{
First isolation of hirame rhabdovirus from freshwater fish in Europe
}

\author{
Borzym E1-, Matras M11, Maj-Paluch J1, Baud Marine², De Boisséson C², Talbi \\ Chiraz, Olesen N J33, Bigarré Laurent ${ }^{2}$ \\ 1 Department of Fish Diseases; National Veterinary Research Institute; Pulawy, Poland \\ 2 Laboratory of Ploufragan- Plouzané; ANSES, European University of Britanny, technopole Brest- \\ Iroise; Plouzané France \\ 3 Fish Diseases Unit (EURL), Section for Virology, National Veterinary Institute; Technical University \\ of Denmark; Frederiksberg C Denmark
}

\begin{abstract}
:
A rhabdovirus was isolated in cell culture inoculated with tissue material from diseased grayling, Thymallus thymallus (L.), originating from a fish farm affected by a mortality episode in Poland. Diagnostics tests showed that the virus was not related to novirhabdoviruses known in Europe, nor to vesiculovirus-like species, except perch rhabdovirus (PRhV) with which it shared moderate serological relations. However, RT-PCR with PRhV probes gave negative results. To identify the virus, a randompriming sequence-independent single primer amplification was adopted. Surprisingly, two of the obtained sequences exhibited a high identity (>99\%) with hirame rhabdovirus (HIRRV), a novirhabdovirus usually found in fish in marine Asiatic countries, for instance Japan, China and Korea. The full-length sequence of the phosphoprotein gene $(P)$ demonstrated a higher identity of the present isolate with HIRRV from China compared with the Korean isolate. An identical viral sequence was also found in brown trout, Salmo trutta trutta L., affected by mortalities in a second farm in the same region, after a likely contamination from the grayling farm. To our knowledge, this is the first report of HIRRV in Europe, and in two hosts from fresh water that have not been described before as susceptible species.
\end{abstract}

Keywords : brown trout, grayling, molecular tracing, outbreak, rhabdovirus, sequence-independent single primer amplification 


\section{Introduction}

2

Hirame rhabdovirus (HIRRV) is one of the four recognized species within the Novirhabdovirus genus, which also includes Viral Hemorrhagic Septicemia Virus (VHSV) and the type species Infectious hematopoietic virus (IHNV). HIRRV was first isolated during an outbreak on cultured flounder (Paralichthys olivaceus T. \& S.) and ayu (Plecoglossus altivelis T. \& S.) in Japan (Kimura, Yoshimizu \& Gorie 1996). It was also found on other marine fish in Asia, such as stone flounder (Kareius bicoloratus J. \& S.) in China (Sun et al. 2010). Experimentally, the virus was shown to be pathogenic on a range of salmonid species in freshwater, including rainbow trout (Oncorhynchus mykiss W.) (Oseko, Yoshimizu \& Kimura 1992). The major clinical signs of HIRRV infection were congestion of the gonads, focal hemorrhage of the skeletal muscle and fins and accumulation of ascitic fluid (Oh \& Choi 1998).

The HIRRV genome is a single-stranded, negative-sense RNA molecule of approximately $11 \mathrm{~kb}$ in length, coding for six proteins: nucleoprotein $(\mathrm{N})$, phosphoprotein $(\mathrm{P})$, matrix protein $(\mathrm{M})$, glycoprotein $(\mathrm{G})$, nonvirion (NV) protein and RNA polymerase (L) (Kim et al. 2005). The first partial sequences were obtained from a Japanese isolate (Nishizawa, Kurath \& Winton 1995, Bjorklund, Higman \& Kurath 1996). Later on, two complete sequences of HIRRV were obtained from Korean and Chinese isolates (Kim et al. 2005, Yingjie et al. 2011). The two full-length genomes exhibited a very high identity level (99\%), the $p$ gene being the most variable (96.9\%).

In 2007, a massive mortality occurred in a grayling farm in Poland. Fish showed clinical signs reminiscent of a viral infection, for instance septicemia and severe bleeding of the internal organs. Few weeks later, a brown trout farm in the same region was also affected by a mortality event, with a suspicion of an infectious disease.

We report hereby that these two episodes were associated with the presence of HIRRV. This is the first detection of HIRRV in Europe and the first time that this virus is associated with mortalities in a freshwater farm.

\section{Fish sampling and virus isolation}

Two pools of pieces of kidneys and spleens were separately collected from graylings (Thymallus thymallus L.) and brown trouts (Salmo trutta L.) originating from two farms in Poland. These two pools of samples were homogenized in Eagle's MEM with Tris buffer, $\mathrm{pH}$ 7.6, supplemented with a $10 \%$ fetal bovine serum (FBS), penicillin $(10000 \mathrm{u} / \mathrm{ml})$, streptomycin $(10 \mathrm{mg} / \mathrm{ml})$ and amphotericin B $(25 \mu \mathrm{g} / \mathrm{ml})$ in a tissue to a 
volume ratio of $1: 10$. After 15 min centrifugation at $4000 \times g$ at $4^{\circ} \mathrm{C}$, the supernatants were filtered through a $0.45 \mu \mathrm{m}$ pore size filter membrane and inoculated on to four cell lines. Epithelioma papulosum cyprini (EPC), fathead minnow (FHM), rainbow trout gonad (RTG) and bluegill fry (BF-2) cell lines were inoculated with the primary dilution and, in addition, a 1:10, 1:100 dilution thereof, resulting in final dilutions of tissue material in cell culture medium of 1:100, 1:1000 and 1:10000, respectively. The cell lines were propagated in 24-wells plates with Eagle's MEM and a Tris buffer supplemented with a 10\% FBS and standard concentrations of antibiotics for $24 \mathrm{~h}$ before infection. The inoculated cell cultures were incubated at $15{ }^{\circ} \mathrm{C}$. The cell cultures were collected for virus identification when the cytopathic effect (CPE) appeared, usually 4 to 7 days after inoculation. The viral isolates from grayling and brown trout were named j.No.207237 and j.No.207238 respectively.

\section{Electron microscopy}

Electron microscopy was carried out on EPC monolayers grown in 24-well tissue culture plates. The cells were inoculated with supernatants from cultures infected with j.No.207237 exhibiting a CPE. At $48 \mathrm{~h}$ post inoculation, cell culture medium was removed and monolayers were fixed in glutaraldehyde $(3 \%$ in $0.1 \mathrm{M}$ sodium cacodylate buffer, $\mathrm{pH} 7.4$ ), postfixed in $2 \%$ osmium tetroxide, dehydrated through graded ethanols and embedded in Lx-112 embedding medium (Ladd Research Industries, Inc.). Ultrathin sections cut in parallel with the monolayer were contrasted in uranyl acetate and lead citrate, and examined with an electron microscope LIBRA120 (Zeiss).

\section{SISPA amplification}

A random-priming sequence-independent single primer amplification (SISPA) was adopted in order to search for viral sequences in the viral isolate from grayling. Total RNA was extracted from a volume of 150 $\mu l$ of supernatant from infected cell culture, using a Nucleospin RNA virus extraction kit (Macherey-Nagel). A volume of $5 \mu \mathrm{l}$ of RNA was reverse-transcribed with primer FR26RV-N and a superscript III kit (Invitrogen) (Djikeng \& Spiro 2009). After treatment with RNAse H, cDNA was purified using a nucleospin extract II kit (Macherey-Nagel) and eluted in $20 \mu \mathrm{l}$ of elution buffer. To produce double-stranded DNA, $7 \mu 1$ of cDNA were treated with $5 \mathrm{u}$ of 3'-5' exo-Klenow DNA polymerase (New England Biolabs) for 30 min at 
$137^{\circ} \mathrm{C}$ in a final volume of $25 \mu 1$. Finally, $2 \mu 1$ were subjected to PCR with 2.5 units of AmpliTaq gold 2 (Applied Biosystems), $2 \mathrm{mM}$ of $\mathrm{MgCl}_{2}$ and 60 pmoles of primer FR20RV with the following steps: a 3 denaturation step of $94{ }^{\circ} \mathrm{C}$ for $8 \mathrm{~min}, 35$ cycles of $94{ }^{\circ} \mathrm{C}$ for $30 \mathrm{sec}, 56{ }^{\circ} \mathrm{C}$ for $30 \mathrm{sec}$ and $72{ }^{\circ} \mathrm{C}$ for $75 \mathrm{sec}$, 4 and a final elongation step at $72{ }^{\circ} \mathrm{C}$ for $7 \mathrm{~min}$. The PCR products were migrated on a $1 \%$ agarose gel, and then stained with ethidium bromide. A smear was observed and products from 0.4 to $1.2 \mathrm{~kb}$ were purified with a Nucleospin kit (Macherey-Nagel) and cloned with the TOPO-TA kit (Invitrogen). Plasmids were extracted from bacterial clones and the inserts sequenced in both orientations according to the Sanger method (Applied Biosystems). Sequences were aligned against the NCBI number database using the BLASTn algorithms.

\section{Specific amplification of HIRRV}

For an accurate genetic identification, specific primers were designed, from a complete sequence already published (FJ376982), in order to amplify the full-length phosphoprotein gene of HIRRV. Primers oPVP278 (5' ACTACAATCAACAAATCGCA 3') and oPVP279 (5' GTTGGCGAGTGGGATGTTG 3') amplify a $730 \mathrm{bp}$ region spanning the whole $p$ gene. First, a volume of $5 \mu 1$ of RNA extracted from infected cell culture supernatant was reverse-transcribed with random hexamers and a thermoscript kit (Invitrogen). For PCR, $2 \mu \mathrm{l}$ of cDNA were amplified with $2.5 \mathrm{U}$ of AmpliTaq gold, $1.5 \mathrm{mM}$ of $\mathrm{MgCl}_{2}$ and 20 pmol of each specific primer in $50 \mu \mathrm{l}$ final, with the following steps: a denaturation of $95{ }^{\circ} \mathrm{C}$ for $8 \mathrm{~min}, 30$ cycles of $94{ }^{\circ} \mathrm{C}$ for $30 \mathrm{sec}, 57{ }^{\circ} \mathrm{C}$ for $30 \mathrm{sec}$ and $72{ }^{\circ} \mathrm{C}$ for $25 \mathrm{sec}$, and a final elongation step at $72{ }^{\circ} \mathrm{C}$ for $7 \mathrm{~min}$. The expected PCR product was cloned and two clones were sequenced. The alignments were performed with VNTI11 (Invitrogen). Various viruses were tested as negative controls, some of them originating from a European proficiency test performed in 2012 (http://www.crl-fish.eu/): Infectious Pancreatic necrosis virus (IPNV) strain Sp, Spring Viremia of Carp Virus (SVCV) strain 56/70, IHNV strain 217/1, VHSV DK-6137 and Infectious Salmon Anemia Virus strain Glesvaer/2/90. A rhabdovirus from perch (France 2012), genetically highly related to the reference strain of PRhV (France 1982) was also used as a negative control (Dorson et al. 1984). 


\section{Results}

2

3

4

\section{Virus isolation}

In April 2007, high mortalities (roughly 80-90\%) affected a grayling farm in the south of Poland at a water temperature of about $11-13{ }^{\circ} \mathrm{C}$. Adult graylings showed clinical signs characteristic from a viral infection, i.e. petechial hemorrhages. Several weeks later, in June, significant mortalities were observed in brown trout in a farm in the same region of Poland, approximately $120 \mathrm{~km}$ from the grayling farm. These brown trout originated from the grayling farm. In affected ponds, fish exhibited abnormal swimming behavior, i.e. spiraling. Lethargy and darkening of the skin were also observed for some individuals. At the peak of the mortality episode, 100 to 200 fish died per day. From the two farms, two pools of samples of clinical cases of graylings and brown trouts were collected and tested in cell culture. A strong cytopathic effect (CPE) was observed in all four cell lines inoculated with each sample of tissue extracts from diseased grayling or brown trout (not shown). CPE was observed within temperature range from 15 to $21^{\circ} \mathrm{C}$, and in the first, second and third passages, which strongly suggested the presence of an infectious virus. The two putative viruses from grayling and brown trout were named njo207237 and njo207238, respectively.

In an attempt to visualize the shape of the virus, EPC cells, inoculated with isolate njo207237, were fixed and prepared for electron microscopy. Bullet-shaped particles were observed in the cytoplasm of the cells, indicating the presence of a rhabdovirus (fig. 1).

\section{Attempts of virus identification}

In an attempt to identify the viral species, several diagnostics methods were used targeting various fish rhabdoviruses. The presence of VHSV, IHNV and Spring Viremia of Carp Virus was tested by ELISA, conventional RT-PCR and Immuno Fluorescence Antibody Test, but no positive signal was recorded (not shown). Interestingly, a weak signal was detected by using seroneutralisation with a rabbit serum against Perch Rhabdovirus (PRhV), a vesiculo-type virus, but not with sera against other vesiculo-type viruses such as SVCV, Pike-Fry Rhabdovirus (PfRV), Tench Rhabdovirus (TRV), Pike rhabdovirus (PRV) or Monta rhabdovirus from Lake trout (MRV) (Table 1) (Bjorklund, Olesen \& Jorgensen 1994, Jorgensen et al. 1993, Koski et al. 1992). Meanwhile, RT-PCR with degenerated primers targeting all vesiculo-type viruses, including PRhV, gave consistently negative results (not shown) (Talbi et al. 2011). This indicated that, 
either the agent is a vesiculo-like virus distantly related to PRhV and, for unknown reasons, not recognized by the generic PCR test, or it belongs to another genus within the Rhabdoviridae.

\section{Identification by SISPA}

In order to identify the rhabdovirus from grayling, a non-specific nucleic acid amplification strategy was attempted. Starting from RNA extracted from cell culture supernatant, cDNA was produced and cloned. Of several hundred clones obtained from the cloning of PCR fragments produced from the random amplification of cDNA, 60 were randomly selected for sequencing. The 60 sequences were submitted to a search in Genbank. Surprisingly, two clones, of 483 and $646 \mathrm{bp}$, exhibited high sequence similarities (> 99\%) with the $\mathrm{N}$ gene and the L gene, respectively, of HIRRV. This viral species had been reported only in Japan, China and Korea until now. The 58 other sequences gave no significant hit. To confirm the presence of HIRRV in grayling and to test if the virus isolated from brown trout virus could also be HIRRV, a specific PCR test was set up, with two primers targeting the whole $p$ gene. For both isolates, these primers readily amplified the expected region confirming the presence of HIRRV in cell culture inoculated with fish extracts (fig. 2). No product was observed when these primers were used with other common fish viruses such as VHSV, IHNV, PRhV, Infectious Pancreatic Necrosis Virus (IPNV) and Infectious Salmon Anemia Virus (ISAV), indicating the specificity of the probes.

The sequences of the $p$ gene of the two isolates from Poland were nearly identical, apart from two substitutions that could be due to PCR artefacts or the quasi-species nature of RNA viruses (fig. 3). Nevertheless, both isolates were more related to the Chinese isolate ( $99 \%$ identity) compared to the isolate from Korea (97\%).

From the seroneutralisation results, it was noticed that the isolate j.No.207237 from grayling exhibited some serological relations with $\mathrm{PRhV}$, although both viruses belong to distinct genera. In order to search putative common motifs, the sequence of the G protein of a HIRRV isolate (from China) was aligned with its homologous part in PRhV (Genbank JF502611). Both sequences exhibited only $18 \%$ of identity and no significant common motif could be found. For comparison, this level of identity was similar for SVCV (16\%), inferior or superior for VHSV (10.5-37\%) and much higher for IHNV (73\%), although isolates of these three viruses tested in our study shared no serological relations with HIRRV j.No.207237 (Kim et al. 2005, Yingjie et al. 2011). The cross-reactions between HIRRV and PRhV remained unexplained. 


\section{Discussion}

4

In 2007, a rhabdovirus was isolated on cell culture from diseased graylings in a farm affected by a mortality episode in Poland. The virus was neither related to the novirhabdoviruses VHSV or IHNV, nor to a range of vesiculo-type Rhabdoviridae. However, serological tests suggested an antigenic relation with PRhV while, a generic RT-PCR targeting all vesiculo-type viruses, including PRhV, gave negative results. To solve this apparent inconsistency, a non-specific amplification strategy was engaged, at a small-scale, to identify a portion of the viral genome. A variant of HIRRV was found without ambiguity. PRhV and HIRRV are very distinct genetically and belong to different genera, although the exact classification of $\mathrm{PRhV}$, relatively to vesiculoviruses, still awaits some decision by the ICTV. The serological link between these two very different species cannot be explained. PRhV-like viruses had previously been isolated from both grayling and brown trout (Johansson et al. 2001, Johansson et al. 2002, Dannevig et al. 2001, Dorson et al. 1984). Therefore, the initial suspicion of PRhV in the samples from Poland was not a surprise. It is unfortunate that an apparent immunological cross reaction between $\mathrm{PRhV}$ and the Polish grayling isolates exists, because it reduces the interest of serological tools in the identification of rhabdoviruses from this species.

In our case, the SISPA method was useful to identify a virus already known, but totally unexpected in this part of the world and on these fish species. The same method has already been used to identify new viruses, including a totivirus causing cardiomyopathy syndrome of Atlantic salmon, although much more sequences were obtained in this case (Haugland et al. 2011). In our work, a small-scale screening was attempted and three factors greatly facilitated the success of the method: the knowledge that a rhabdovirus was implicated, the possibility of producing it at high titres in cell culture and the availability of homologous genetic data sequences in Genbank. In the present case, only a low percentage (about 6\%) of cloned DNA represented the viral genome. This was enough for a virus identification, but not for a full-length genomic covering. This percentage could have been higher by purifying the virus or nucleases treatments to remove host nucleic acids before viral RNA extraction. Finally, this method appears fully affordable and moderately time-consuming, and therefore should be standardized in all structures likely to isolate new viruses found during routine screenings or outbreaks, for instance national reference laboratories. 
By using a specific RT-PCR, a second isolate of HIRRV was identified in a cell culture inoculated with extracts of brown trout originating from another mortality event in a farm in Poland, distant of $120 \mathrm{~km}$ from the grayling farm. Both isolates from Poland shared $100 \%$ similarity of the $\mathrm{P}$ gene, making an epidemiological link between the two farms likely. Indeed, the brown trouts originated from the grayling farm and made it plausible that the case was due to horizontal contamination between the two fish species by close contact.

The origin of an Asiatic marine virus in two freshwater farms in Poland is intriguing. A source of virus could be frozen fish, bought in Asia, that was used by the farmer as feed in the grayling farm. It is generally admitted that both gutted and round fish used as feed is a possible source of rhabdovirus transmission in farms or in the wild (Oidtmann et al. 2011, Skall, Olesen \& Mellergaard 2005). For instance, freezing-thawing fish infected with VHSV reduces, but do not abolish, the infectivity of the virus (Arkush et al. 2006). Unfortunately, in the present case, no feed sample was available for analysis and it was not possible to verify this hypothesis.

Several factors indicate that lines the HIRRV caused the mortalities in the two farms. First, the virus was found in the two episodes, and an epidemiological link was evidenced with a transfer of fish from one farm to the other. Second, the virus was isolated in cell culture at the first passage indicating a moderate to high titre in the fish. Third, no other virus was found among the few other tested. Fourth, a possible origin of the virus was found, via the imported food. Nevertheless, experimental infections should be performed to prove definitively the implication of HIRRV in the pathology.

The factors of virulence should be further investigated to estimate the epizootic risks in Europe on grayling and other freshwater fish species. It must be mentioned that in the same period than during the viral isolation, a massive mortality occurred on wild grayling in a river in the same region of the grayling farm. Unfortunately, no samples could be analyzed at that time, but the possibility of an HIRRV outbreak in the wild is hypothesized. Indeed, the grayling farm is connected to the river and a release of virus was inevitable. Alternatively, since repopulating rivers with grayling is common in Poland, the possibility that infected grayling were released in the river is raised. It is therefore urgent to proceed to a routine surveillance of the fish in the mentioned river, which is also flowing in a neighbor country.

\section{Acknowledgments}


1 The authors would like to thank Professor Jerzy Antychowicz for helpful comments on the manuscript. We

2 also thank Agnieszka Sandomierska and Maria Wejman and Mette Eliassen for excellent technical support.

3 This study was partially supported by the EU "Network of Excellence, EPIZONE" and the MAEI office of

ANSES.

\section{Literature cited}

Arkush, K.D., Mendonca, H.L., Mcbride, A.M., Yun, S., Mcdowell, T.S. \& Hedrick, R.P. (2006) Effects of temperature on infectivity and of commercial freezing on survival of the North American strain of viral hemorrhagic septicemia virus (VHSV). Diseases of Aquatic Organisms, 69, 145-151.

Bjorklund, H., Olesen, N.J. \& Jorgensen, P.E.V. (1994) Biophysical and serological characterization of rhabdovirus 903/87 isolated from European lake trout Salmo trutta lacustris. Diseases of Aquatic Organisms, 19, 21-26.

Bjorklund, H.V., Higman, K.H. \& Kurath, G. (1996) The glycoprotein genes and gene junctions of the fish rhabdoviruses spring viremia of carp virus and hirame rhabdovirus: analysis of relationships with other rhabdoviruses. Virus Research, 42, 65-80.

Dannevig, H., Olesen, N.J., Jentoft, S., Kvellestad, A., Taksdal, T. \& Hastein, T. (2001) The first isolation of a rhabdovirus from perch (Perca fluviatilis) in Norway. Bulletin of the European Association for Fish Pathology, 21.

Djikeng, A. \& Spiro, D. (2009) Advancing full length genome sequencing for human RNA viral pathogens. Future Virology, 4, 47-53.

Dorson, M., Torchy, C., Chilmonczyk, S. \& De Kinkelin, P. (1984) A rhabdovirus pathogenic for perch, Perca fluviatilis L.: isolation and preliminary study. Journal of Fish Diseases, 7, 241-245.

Haugland, O., Mikalsen, A.B., Nilsen, P., Lindmo, K., Thu, B.J., Eliassen, T.M., Roos, N., Rode, M. \& Evensen, O. (2011) Cardiomyopathy syndrome of atlantic salmon (Salmo salar L.) is caused by a double-stranded RNA virus of the Totiviridae family. Journal of Virology, 85, 5275-5286.

Johansson, T., Nylund, S., Olesen, N.J. \& Bjorklund, H. (2001) Molecular characterisation of the nucleocapsid protein gene, glycoprotein gene and gene junctions of rhabdovirus 903/87, a novel fish pathogenic rhabdovirus. Virus Research, 80, 11-22.

Johansson, T., Ostman-Myllyoja, L., Hellstrom, A., Martelius, S., Olesen, N.J. \& Bjorklund, H. (2002) A novel fish rhabdovirus from sweden is closely related to the Finnish rhabdovirus 903/87. Virus Genes, 25, 127-138.

Jorgensen, P.E.V., Olesen, N.J., Ahne, W., Wahli, T. \& Meier, W. (1993) Isolation of a previously undescribed rhabdovirus from pike Esox lucius. Diseases of Aquatic Organisms, 16, 171-179.

Kim, D.H., Oh, H.K., Eou, J.I., Seo, H.J., Kim, S.K., Oh, M.J., Nam, S.W. \& Choi, T.J. (2005) Complete nucleotide sequence of the hirame rhabdovirus, a pathogen of marine fish. Virus Research, 107, 1-9.

Kimura, T., Yoshimizu, M. \& Gorie, S. (1996) A new rhabdovirus isolated in Japan from cultured hirame (Japanese flounder) Paralichthys olivaceus and ayu Plecoglossus altivelis. Diseases of Aquatic Organisms, 1, 209-217.

Koski, P., Hill, B.J., Way, K., Neuvonen, E. \& Rintamaki, P. (1992) A rhabdovirus isolate from brown trout (Salmo trutta m. lacustris (L.)) with lesions in parenchymatous organs. Bulletin of the European Association for Fish Pathology, 12.

Nishizawa, T., Kurath, G. \& Winton, J.R. (1995) Nucleotide sequence of the 2 matrix protein genes (M1 and M2) of hirame rhabdovirus (HRV), a fish rhabdovirus. Veterinary Research, 26, 408-412.

Oh, M.J. \& Choi, T.J. (1998) A new rhabdovirus (HRV-like) isolated in Korea from cultured Japanese flounder Paralichthys olivaceus. Journal of Fish Pathology 11, 129-136.

Oidtmann, B., Joiner, C., Reese, R.A., Stone, D., Dodge, M. \& Dixon, P. (2011) Risks associated with commodity trade: transmission of viral haemorrhagic septicaemia virus (VHSV) to rainbow trout fry from VHSV-carrying tissuehomogenates. Transboundary and Emerging Diseases, 58, 224-231. 
Oseko, N., Yoshimizu, M. \& Kimura, T. (1992) Pathogenicity of Rhabdovirus olivaceus (Hirame rhabdovirus; HRV) for salmonid fish. In: Proceedings of the OJI International on Salmonid Diseases. Hokkaido University Press, Sapporo, Japan.

Skall, H.F., Olesen, N.J. \& Mellergaard, S. (2005) Prevalence of viral haemorrhagic septicaemia virus in Danish marine fishes and its occurrence in new host species. Diseases of Aquatic Organims, 66, 145-151.

Sun, Y., Yue, Z., Liu, H., Zhao, Y., Liang, C., Li, Y., Shi, X., Wu, B., Xu, B., Deng, M., Zhu, L. \& Wang, Z. (2010) Development and evaluation of a sensitive and quantitative assay for hirame rhabdovirus based on quantitative RT-PCR. Journal of Virological Methods, 169, 391-396.

Talbi, C., Cabon, J., Baud, M., Bourjaily, M., De Boisseson, C., Castric, J. \& Bigarré, L. (2011) Genetic diversity of perch rhabdoviruses isolates based on the nucleoprotein and glycoprotein genes. Archives of Virology, 156, 21332144.

Yingjie, S., Min, Z., Hong, L., Zhiqin, Y., Xiaocong, Z. \& Zhe, W. (2011) Analysis and characterization of the complete genomic sequence of the Chinese strain of hirame rhabdovirus. Journal of Fish Diseases, 34, 167-171. 


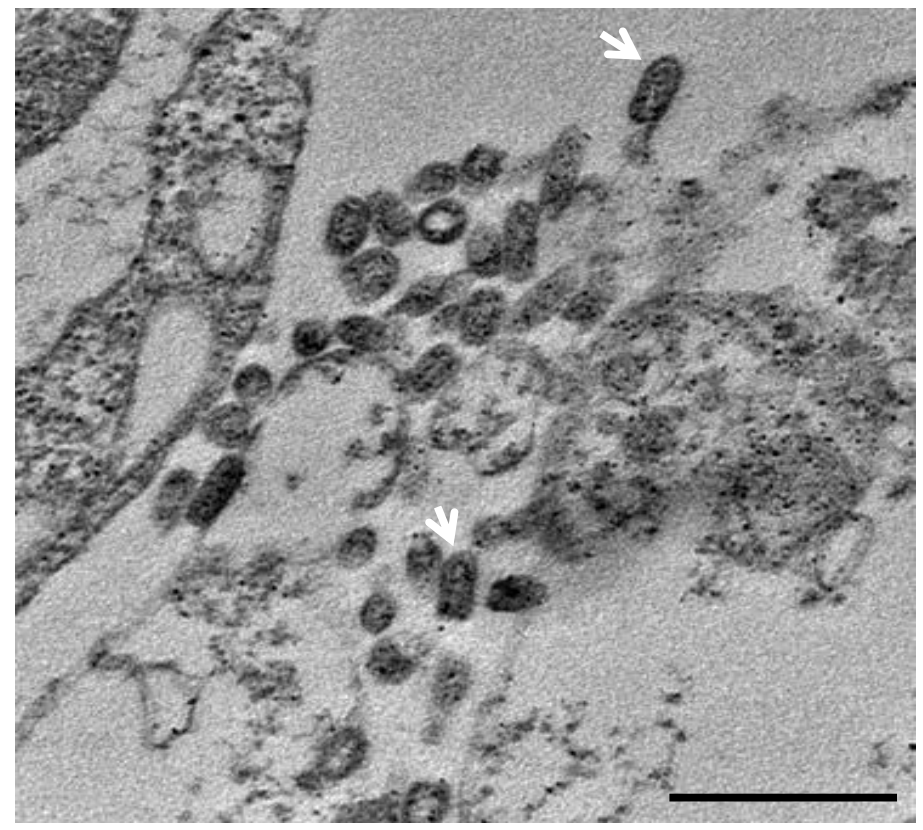

Figure 1 Ultrathin sections observed by electron microscopy of EPC cells infected with the virus from grayling. Typical bulled-shaped viral particles are visible (arrows). Bar $=500 \mathrm{~nm}$ 


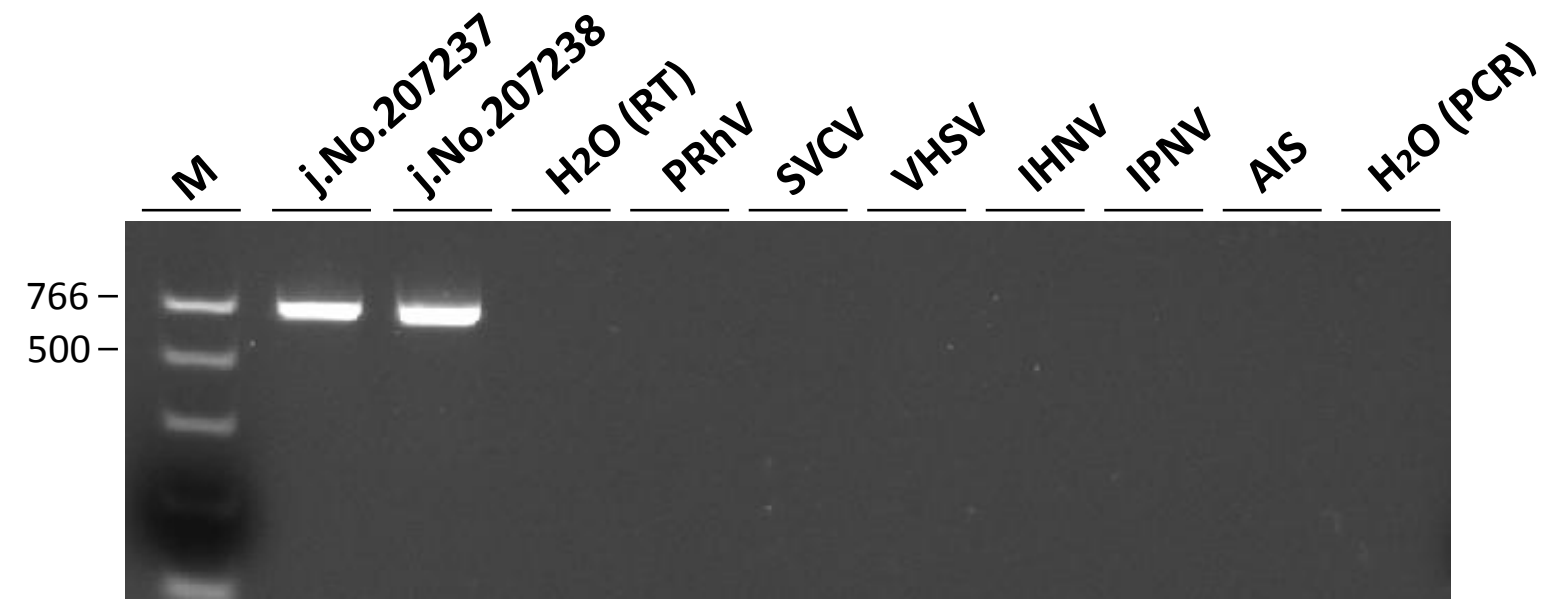

Figure 2 PCR with primers targeting the $p$ gene of HIRRV. The two isolates from Poland were tested as well as other viruses produced in cell culture: 4 rhabdoviruses (PRhV, SVCV, VHSV, and IHNV), an aquabirnavirus (IPNV) and an orthomyxovirus (ISAV). Two negative controls with water were added either at the reverse transcription (RT) step or the PCR step. M, PCR ladder (NEB). The products were migrated in a $2 \%$ agarose gel, pre-stained with $\mathrm{EtBr}$ (Invitrogen). 


\begin{tabular}{|c|c|c|c|c|c|c|c|c|c|c|}
\hline Antisera & $\begin{array}{c}\text { SVCV } \\
\text { F75 }\end{array}$ & $\begin{array}{c}\text { PFR } \\
\text { K44 }\end{array}$ & $\begin{array}{c}\text { PFR } \\
\text { F30 }\end{array}$ & $\begin{array}{c}\text { PRV } \\
\text { LGV } \\
\text { K2102 }\end{array}$ & $\begin{array}{c}\text { TRV } \\
\text { F56 }\end{array}$ & $\begin{array}{c}\text { TRV } \\
\text { F55 }\end{array}$ & $\begin{array}{c}\text { PRhV } \\
\text { F28 }\end{array}$ & $\begin{array}{c}\text { PRhV } \\
\text { F27 }\end{array}$ & $\begin{array}{c}\text { MRV } \\
\text { K3005 }\end{array}$ & $\begin{array}{c}\text { Control } \\
\text { rabbit }\end{array}$ \\
\hline $\begin{array}{c}50 \% \text { SNT } \\
\text { titres of } \\
\text { virus } \\
\text { j.No.207237 }\end{array}$ & $<\mathbf{4 0}$ & $<\mathbf{4 0}$ & $<\mathbf{4 0}$ & $<\mathbf{4 0}$ & $<\mathbf{4 0}$ & $<\mathbf{4 0}$ & $\mathbf{3 2 0}$ & $\mathbf{8 0}$ & $<\mathbf{4 0}$ & $<\mathbf{4 0}$ \\
\hline
\end{tabular}

Table 1 Serum neutralization test of isolate j.No.207237 against a panel of rabbit antisera raised against aquatic vesiculo-type viruses. MRV 'Monta' Rhabdovirus, PFR Pike fry rhabdovirus, PRV Pike rhabdovirus, SVCV Spring Viremia of Carp virus, TRV Tench rhabdovirus. 